\title{
Assessing Relationships Among Properties of Demolished Concrete, Recycled Aggregate and Recycled Aggregate Concrete using Regression Analysis
}

\author{
Vivian W. Y. Tam ${ }^{1 *}$, K. Wang ${ }^{2}$ and C. M. Tam ${ }^{2}$ \\ ${ }^{1}$ * Correspondence Author, Griffith School of Engineering, Gold Coast Campus, Griffith \\ University PMB50 Gold Coast Mail Centre, Qld 9726, Australia; \\ Email:v.tam@griffith.edu.au. \\ 2 Department of Building \& Construction, City University of Hong Kong, 83 Tat Chee Avenue, \\ Kowloon, Hong Kong; Email: bctam@cityu.edu.hk.
}

Abstract. Recycled demolished concrete (DC) as recycled aggregate (RA) and recycled aggregate concrete (RAC) is generally suitable for most construction applications. Lowgrade applications, including sub-base and roadwork, have been implemented in many countries; however, higher-grade activities are rarely considered. This paper examines relationships among DC characteristics, properties of their RA and strength of their RAC using regression analysis. Ten samples collected from demolition sites are examined. The results show strong correlation among the DC samples, properties of RA and RAC. It should be highlighted that inferior quality of DC will lower the quality of RA and thus their RAC. Prediction of RAC strength is also formulated from the DC characteristics and the RA properties. From that, the RAC performance from DC and RA can be estimated. In addition, RAC design requirements can also be developed at the initial stage of concrete demolition. Recommendations are also given to improve the future concreting practice.

Keywords: Demolished concrete, recycled aggregate, recycled aggregate concrete, regression analysis, correlation. 


\section{Introduction}

Construction debris resulting from construction and demolition (C\&D) work constitutes a large proportion of solid waste as shown in Table 1. In the United Kingdom, more than $50 \%$ of waste deposited in a typical landfill comes from construction [1]; while about 70 million tonnes of waste are from C\&D activities annually [2]. In Australia, about 14 million tonnes of waste have been put into landfill each year, in which about $44 \%$ of waste is attributed to the construction industry [3, 4]. In the United States of America, about $29 \%$ of solid-waste is from construction [5], while in Hong Kong, it is about 38\% [6].

$<$ Table 1>

Among various types of construction materials, concrete was found to be the most significant element, about 75\%,70\%, 40\% and 70\% collected from construction sites, demolition sites, general civil work and renovation work respectively (see Table 2).

$<$ Table 2>

Because of the fast generation of C\&D waste, the Hong Kong government pushed very hard to promote the use of recyclable C\&D materials. The Environment, Transport and Works Bureau of the Hong Kong Special Administrative Region (SAR) had issued a technical circular (Ref: 15/2003) on "waste management on construction sites". Various types of materials are sorted before being sent out from construction sites, including all excavated materials, metal, cardboard and paper packaging, plastic, chemical waste and others. The Housing Authority of the Hong Kong SAR has implemented selective demolition methods in school projects at Lower Ngau Tau Kok Phase 1 Estate. Different 
types of materials are sorted, including timber, steel, florescent tubes, electricity fitting, toilet sets, brick, tiles, finishes, drainage pipes, cables, to improve the recycling rates.

To encourage the adoption of RA, Buildings Department of the Hong Kong SAR issued a practice note for authorised persons and registered structured engineers entitled "Use of RA in concrete" in February 2003 [6] to encourage the adoption of RA in construction activities. The use of RA in concrete is only at its initial stage of implementation. Civil Engineering Department of the Hong Kong SAR is commissioning a pilot recycling plant at Tuen Mun Area 38 with a view to supply RA to a number of public work projects earmarked for such purposes. All RA produced needs to fulfill the requirements set by Buildings Department of the Hong Kong SAR.

Although the Hong Kong government has established some guidelines and specifications for construction, the Hong Kong recycling practice is still lagging behind other countries because many recyclable materials are still being dumped as waste. There are many opportunities for the industry to improve waste management and recycling [7] to prolong the landfill life, to minimize transport needs and to reduce primary resource requirements (mineral and energy).

\section{Research Objectives}

This paper focuses on:

- Experimenting the characteristics of DC, properties of RA and strength of RAC where samples are collected from demolition sites; 
- Analyzing the correlation among the characteristics of DC samples, and properties of their RA and RAC by regression analysis;

- Formulating relationships among properties of DC, RA and RAC; and

- Recommending measures to improve concrete quality for the future concreting activities.

\section{Obstacles in the Use of Demolished Concrete Waste}

A disadvantage of demolished concrete waste is its low density, and as a result its high porosity. Hence, more water is required to ensure full saturation of RA during concrete mixing and it may also require more intensive compaction. Although the RAC applications are only employed for low-grade activities, certain percentages of natural materials can be saved. Most re-utilized waste is considered as roughly broken material processed for lowgrade applications. However, demolition techniques generating recycled materials can be controlled to produce end-products suitable for high-grade applications. Currently, only about $4 \%$ of this waste is sorted, crushed and graded to be reused as an alternative primary aggregate for road construction [8].

\section{Materials and Methods}

Ten samples (Samples 1 to 10) from ten demolition sites are collected to investigate their characteristics and properties. Sample 1 is located next to the Victoria Harbour; Samples 2, 6 and 8 are partially located next to open space; and the other samples are located next to residential, commercial, industrial buildings or school areas. A summary of the sample 
collection locations is schematically shown in Figure 1. Four DC characteristics are examined: i) density; ii) absorptivity; iii) porosity; and iv) carbonation depth.

\section{$<$ Figure 1>}

A jaw crusher is used to crush the DC samples into $20 \mathrm{~mm}$ and $10 \mathrm{~mm}$ aggregate for producing RA and RAC which properties are investigated. Six groups of RA properties: i) particle size distribution; ii) particle density; iii) porosity and absortion; iv) particle shape; v) strength and toughness; and vi) chloride and sulphate contents, and compressive strength of RAC are investigated.

All experimental work is conducted according to British Standards summarized in Table 3. Average results from three tests on each property of DC, RA and RAC are reported in this paper.

$<$ Table 3>

\section{Results and Discussions}

Summaries of the characteristics of the DC samples, the properties of their RA and the compressive strength of the RAC are shown in Table 4, Table 5 and Table 6 respectively.

$<$ Table 4>

$<$ Table 5>

$<$ Table 6> 
To investigate relationships among properties of DC, RA and RAC from the samples, a correlation table is prepared as shown in Table 7 which clearly shows strong correlation among the properties of DC, RA and RAC. The correlation coefficients are measured; some achieved up to 0.995 .

$<$ Table 7>

\subsection{Demolished Concrete}

\subsubsection{Density}

As cement mortar density of around 1.0 to $1.6 \mathrm{Mg} / \mathrm{m}^{3}$ is less than that of natural aggregate particles at around $2.6 \mathrm{Mg} / \mathrm{m}^{3}[9,10]$, the lower the density of DC samples, the higher the cement mortar content will be. From the results in Table 4, it is found that the variation of density ranges between $2,269 \mathrm{~kg} / \mathrm{m}^{3}$ (Sample 8) and 2,432 kg/m ${ }^{3}$ (Sample 6).

From the results shown in Table 7, it is found that there is a correlation between density and other properties of DC as evidenced by regression equations and R-square values. A regression equation describes a line or a curve in a two-dimensional or two-variable space defined by the equation $Y=a+b * X$; and R-square is a regression coefficient describing the correlation of raw data to the line or curve defined by the regression equation, which reflects the accuracy level of the prediction model. Equation 1, Equation 2 and Equation 3 show the relationships between density and absorptivity; and porosity, and carbonation depth respectively.

$$
A_{d c}=-0.0265 D_{d c}+67.459 \quad\left(R^{2} \approx 0.6854\right) \quad \text { Equation } 1
$$




$$
\begin{array}{lll}
P_{d c}=-0.0231 D_{d c}+70.472 & \left(R^{2} \approx 0.5637\right) & \text { Equation } 2 \\
C D_{d c}=-0.0115 D_{d c}+28.303 & \left(R^{2} \approx 0.6121\right) & \text { Equation 3 }
\end{array}
$$

where $D_{d c}$ is the density of the DC samples (in $\mathrm{kg} / \mathrm{m}^{3}$ ); $A_{d c}$ the absorptivity of the DC samples (in \%); $P_{d c}$ the porosity of the DC samples (in \%); and $C D_{d c}$ the carbonation depth index of the DC samples.

\subsubsection{Absorptivity}

Cement paste has a relatively higher absorptivity than that of the aggregate. The higher the absorptivity of the DC, the more cement paste attached on the samples will be. Table 4 shows the absorptivity of the ten DC samples. It is found that Sample 7 has the highest absorptivity of about $8.93 \%$ while Sample 6 has the lowest of about $1.98 \%$.

From the results shown in Table 7, there is a correlation between absorptivity and porosity, and carbonation depth as shown in Equation 4 and Equation 5 respectively.

$$
\begin{array}{lll}
P_{d c}=0.8088 A_{d c}+11.975 & \left(R^{2} \approx 0.7077\right) & \text { Equation } 4 \\
C D_{d c}=0.3984 A_{d c}-0.7257 & \left(R^{2} \approx 0.7563\right) & \text { Equation } 5
\end{array}
$$

\subsubsection{Porosity}

Porosity of DC is closely related to the content of cement mortar in the samples as explained in Section 5.1.1 and 5.1.2 [11-17]. The more cement mortar content in the samples, the lower their density, the higher their absorptivity and porosity will be. Experimental results on mercury intrusion porosimetry (MIP) are summarised in Table 4, 
which is designed to investigate the porosity of the DC samples. Sample 7 has the highest porosity of about $20.41 \%$ while Sample 2 has the lowest of about $13.94 \%$.

From the correlation table shown in Table 7, there is a correlation between porosity and carbonation depth of the DC samples as shown in Equation 6.

$$
C D_{d c}=0.425 P_{d c}-5.5397 \quad\left(R^{2} \approx 0.7957\right) \quad \text { Equation } 6
$$

\subsubsection{Carbonation Depth}

To compare the carbonation depth among the samples, the Fourier transform of infrared spectroscopy (FT-IR) is used. Five layers of cement paste around aggregate are studied (see Figure 2). Quantities of carbon oxide $(\mathrm{CO})$ and carbon dioxide $\left(\mathrm{CO}_{2}\right)$ on each layer are examined. Carbonation depth index (CDI) is used for analysis which is estimated using Equation 7.

$$
\text { Carbonation depth index }(C D I)=\frac{\sum_{n=1}^{4} Q_{c n}-Q_{c 5}}{Q_{c 5}}
$$

where $Q_{C n}$ is the quantity of $\mathrm{CO}$ or $\mathrm{CO}_{2}$ of the ${ }^{\text {th }}$-layer of cement paste, $Q_{C 5}$ the quantity of $\mathrm{CO}$ or $\mathrm{CO}_{2}$ of the fifth layer of cement paste and $Q_{C n}$ should be larger than $Q_{C 5}$.

$<$ Figure 2>

$\mathrm{CO}_{2}$ in the atmosphere reacts in the presence of moisture with hydrated cement minerals. Reaction of $\mathrm{CO}_{2}$ takes place even at small concentrations such as rural air where $\mathrm{CO}_{2}$ content is about $0.03 \%$. In an unventilated laboratory, the content may rise to above $0.1 \%$. In large cities, it is about $0.3 \%$ and in some exceptional cases, it can increase to $1 \%$ [10]. 
The carbonation rate increases when the concentration of $\mathrm{CO}_{2}$ increases, especially with a high water to cement ratio. Carbonation takes places when calcium hydroxide $\left[\mathrm{Ca}(\mathrm{OH})_{2}\right.$ or $\mathrm{CH}$ ] [18]. The reaction has also led to the formation and accumulation of calcium carbonate $\left(\mathrm{CaCO}_{3}\right)$ as shown in Equation 8 to Equation 11. $\mathrm{CO}_{2}$ of the $\mathrm{CaCO}_{3}$ is generated (see Equation 12) during carbonation and $\mathrm{CO}$ is generated after the generation of the $\mathrm{CO}_{2}$ as shown in Equation 13.

\begin{tabular}{|c|c|c|}
\hline $\mathrm{Ca}(\mathrm{OH})_{2}+\mathrm{CO}_{2}$ & $\rightarrow \mathrm{CaCO}_{3}+\mathrm{H}_{2} \mathrm{O}$ & Equation 8 \\
\hline \multirow[t]{2}{*}{ Calcium silicate hydrate $+\mathrm{CO}_{2}$} & $\rightarrow$ various intermediates & Equation 9 \\
\hline & $\rightarrow \mathrm{CaCO}_{3}+\mathrm{SiO}_{2} \mathrm{nH}_{2} \mathrm{O}+\mathrm{H}_{2} \mathrm{O}$ & \\
\hline Aluminate hydrates $+\mathrm{CO}_{2}$ & $\rightarrow \mathrm{CaCO}_{3}+$ hydrated alumina & Equation 10 \\
\hline \multirow[t]{2}{*}{ Ferrite hydrates $+\mathrm{CO}_{2}$} & $\rightarrow \mathrm{CaCO}_{3}+$ hydrated alumina and iron & Equation 11 \\
\hline & oxides & \\
\hline $\mathrm{CaCO}_{3}$ & $\rightarrow \mathrm{CaO}+\mathrm{CO}_{2}$ & Equation 12 \\
\hline $2 \mathrm{CO}_{2}$ & $\rightarrow 2 \mathrm{CO}+\mathrm{O}_{2}$ & Equation 13 \\
\hline
\end{tabular}

Carbonation has a deleterious effect on hardened cement paste as it appears to decrease strength and increase porosity [18-20]. Major controlling factors affecting carbonation concentration are water to cement ratios, aggregate porosities, curing and the environment of exposed structures [18]. The carbonation depth is roughly proportional to the square-root of time, doubling between one year and four years, then again doubling between four and ten years; there is probably a further doubling up to 50 years [10]. An extensive survey by Brown [21] found that carbonation depths correlated well with concrete quality but there was no significant relationship with reported exposure conditions. In general, any factors, 
which increase concrete permeability, can also increase the carbonation rate, provided that necessary internal moisture conditions are present. The carbonation reaction rate depends on the moisture content of concrete and relative humidity of the ambient medium $[18,10]$. In addition, carbonation depth increases with an increase in water to cement ratio; for example, at a water to cement ratio of about 0.4 , the depth is only half of that about 0.6 ; at a water to cement ratio of about 0.8 , the depth is $50 \%$ greater than at about 0.6 . A typical depth at a water to cement ratio of about 0.5 after normal exposure for 10 years is between $5 \mathrm{~mm}$ and $10 \mathrm{~mm}[10]$.

From the FT-IR results, it can be observed that there is a gradual increase in the total absorbance of $\mathrm{CO}$ and $\mathrm{CO}_{2}$ in the samples. An example of the change in gradient is shown in Figure 3. Theoretically, cement paste far from inner aggregate should be exposed to a higher degree of carbonation. Therefore, the total absorbance of $\mathrm{CO}$ and $\mathrm{CO}_{2}$ should be gradually decreasing from the $5^{\text {th }}$ layer to the $1^{\text {st }}$ layer of cement paste. However, the results from the samples show that the total absorbance of $\mathrm{CO}$ and $\mathrm{CO}_{2}$ in the near layers to aggregate, such as the $1^{\text {st }}$ or $2^{\text {nd }}$ layers of cement paste, is higher. From the results shown in Table 4, Sample 7 has the highest CDI of about 3.38 while Sample 6 has the lowest of about 0.41 . The CDI difference among various samples is quite large.

\section{$<$ Figure 3>}

In this section, all characteristics of the DC samples are shown to correlate among each other. Therefore, either "density", "absorptivity", "porosity" or "carbonation depth" is enough for describing the characteristics of the DC samples. 


\subsection{Recycled Aggregate}

\subsubsection{Particle Size Distribution}

Particle size distribution is important in affecting concrete workability [10]. The collected samples all fulfill the particle size distribution of $10 \mathrm{~mm}$ and $20 \mathrm{~mm}$ aggregate as stated in BS 882 [22] as shown in Table 5. "Pass" in Table 5 means the grading of the aggregate is within the upper and lower boundary requirements as stated in the British Standard for concrete workability.

\subsubsection{Particle Density}

Aggregate particle density is an essential property for concrete mix design and also for calculating concrete volume produced from a certain mass of materials [23], which is a ratio of mass on a given volume to the mass of the same water volume [24]. Particle densities are measured and presented in Table 5.

As discussed in Section 5.1.1, the lower the density, the higher the cement mortar content attached to the RA will be. Samples 7 and 8 have the lowest values of particle density, indicating the highest amount of cement mortar attached to RA in Samples 7 and 8 compared with other samples; while Sample 6 has the highest value of particle density. Furthermore, particle densities of $20 \mathrm{~mm}$ aggregate are larger than those of $10 \mathrm{~mm}$ aggregate, inferring a higher amount of cement mortar attached to the $10 \mathrm{~mm}$ aggregate. This implies that the larger the size of the aggregate, the smaller the percentage of cement mortar attached to its surfaces and the better the aggregate quality will be. 
Equation 14 shows the relationship between density for $10 \mathrm{~mm}$ and $20 \mathrm{~mm}$ aggregate.

$$
D_{\text {ra20 }}=0.7311 D_{\text {ra10 }}+0.5961 \quad\left(R^{2} \approx 0.5198\right) \quad \text { Equation } 14
$$

where $D_{\text {ralo }}$ is the particle density for $10 \mathrm{~mm}$ aggregate (in $\%$ of dry mass); and $D_{\text {razo }}$ the particle density for $20 \mathrm{~mm}$ aggregate (in \% of dry mass).

Table 7 shows the correlation of particle densities with water absorption rates of the RA samples. Equation 15 and Equation 16 show the relationships between particle density and water absorption for $10 \mathrm{~mm}$ and $20 \mathrm{~mm}$ aggregate respectively.

$$
\begin{array}{lll}
W A_{\text {ra } 10}=-18.014 D_{\text {ra } 10}+46.295 & \left(R^{2} \approx 0.6304\right) & \text { Equation } 15 \\
W A_{\text {ra } 20}=-11.206 D_{\text {ra } 20}+31.325 & \left(R^{2} \approx 0.5956\right) & \text { Equation } 16
\end{array}
$$

where $W A_{\text {ralo }}$ is the water absorption rate for $10 \mathrm{~mm}$ aggregate (in $\%$ of dry mass); and $W A_{\text {razo }}$ the water absorption rate for $20 \mathrm{~mm}$ aggregate (in $\%$ of dry mass).

Based on Equation 15 to Equation 16, the parameters which can be used to measure the particle density exhibit strong correlation to the water absorption values of the RA; for example, when the particle density is obtained, water absorption can be determined at an accuracy of about $60 \%$ significance. Savings in time and resources in carrying out all tests can thus be achieved, leading to higher efficiency in adopting RA for new construction work. By reducing the number of RA tests, shorter RA evaluation time can be achieved. 
In addition, the particle densities of the RA samples also show relationships with density, absorptivity, porosity, and carbonation depth for the DC samples as shown in Equation 17 to Equation 23.

$$
\begin{array}{lll}
D_{d c}=1182.1 D_{\text {ra10 }}-217.72 & \left(R^{2} \approx 0.829\right) & \text { Equation } 17 \\
D_{d c}=872.48 D_{\text {ra20 }}+448.48 & \left(R^{2} \approx 0.4644\right) & \text { Equation } 18 \\
A_{d c}=-31.844 D_{\text {ra10 }}+74.468 & \left(R^{2} \approx 0.5892\right) & \text { Equation } 19 \\
A_{d c}=-29.596 D_{\text {ra20 }}+69.863 & \left(R^{2} \approx 0.5234\right) & \text { Equation } 20 \\
P_{d c}=-31.519 D_{\text {ralo }}+84.768 & \left(R^{2} \approx 0.6245\right) & \text { Equation } 21 \\
C D_{d c}=-14.146 D_{\text {ralo }}+32.124 & \left(R^{2} \approx 0.5541\right) & \text { Equation } 22 \\
C D_{d c}=-14.619 D_{\text {ra20 }}+33.301 & \left(R^{2} \approx 0.6085\right) & \text { Equation 23 }
\end{array}
$$

\subsubsection{Porosity and Absorption}

Overall aggregate porosity or absorption may depend upon consistent degree of particle porosity or represent an average value for a mixture of variously high and low absorption materials [23]. In this study, water absorption rate is used to assess the porosity and absorption levels of the samples.

The water absorption of the RA samples 1 to 10 is varied as shown in Table 5. Sample 7 exhibits the highest water absorption rate at about 8.74\%, and Sample 6 has the lowest water absorption rate at about $5.20 \%$ for $10 \mathrm{~mm}$ aggregate. One of the most obvious attributes between RA and natural aggregate is the higher water absorption rate of RA, which is mainly affected by the amount of cement paste attached on the aggregate surface that describes the soundness of aggregate since porosity of cement mortar is higher than 
that of aggregate. RA with a higher absorption rate tends to be weaker in strength and resistance to freezing and thawing than normal aggregate [25-27].

Equation 24 shows the relationship between water absorption values for $10 \mathrm{~mm}$ and $20 \mathrm{~mm}$ aggregate.

$$
W A_{\text {ra } 20}=0.4744 W A_{\text {ralo }}+3.4508 \quad\left(R^{2} \approx 0.5344\right) \quad \text { Equation } 24
$$

The water absorption for the RA samples shows relationships with density, water absorption, porosity, and carbonation depth for the DC samples as shown in Equation 25 to Equation 31.

$$
\begin{array}{llr}
D_{d c}=-43.063 W A_{r a 10}+2661.7 & \left(R^{2} \approx 0.5664\right) & \text { Equation } 25 \\
D_{d c}=-78.657 W A_{r a 20}+2892.7 & \left(R^{2} \approx 0.7958\right) & \text { Equation } 26 \\
A_{d c}=1.5503 W A_{r a 10}-5.8422 & \left(R^{2} \approx 0.7189\right) & \text { Equation } 27 \\
A_{d c}=2.0337 W A_{r a 20}-8.7474 & \left(R^{2} \approx 0.521\right) & \text { Equation } 28 \\
P_{d c}=1.5476 W A_{r a 10}+5.1867 & \left(R^{2} \approx 0.7751\right) & \text { Equation 29 } \\
C D_{d c}=0.715 W A_{r a 10}-3.7371 & \left(R^{2} \approx 0.7287\right) & \text { Equation } 30 \\
C D_{d c}=0.9367 W A_{r a 20}-5.0688 & \left(R^{2} \approx 0.5267\right) & \text { Equation } 31
\end{array}
$$

\subsubsection{Particle Shape}

Characteristics and variations of aggregate particle shape can affect workability and strength of concrete [23]. The shape of aggregate particles is best described by two principal parameters: 'sphericity' and 'roundness'. Aggregate particles are classified as flaky when they have the thickness (smaller dimension) of less than about 0.6 of their mean 
sieve size, for example, a mean sieve size of about $7.5 \mathrm{~mm}$ is the mean of two successive sieves of $5 \mathrm{~mm}$ and $10 \mathrm{~mm}$ [28]. Aggregate particles are classified as elongated when they have a length (greatest dimension) of more than about 1.8 of their mean sieve size [29].

BS 882 [22] provides limits for the flakiness (particle thickness relative to other dimensions). BS 882 [22] limits the flakiness index determined in accordance with BS 812: Part 105:1 [28] to about 50\% for uncrushed gravel and about $40 \%$ for crushed rock or crushed gravel, with a warning that lower values may be specified for special circumstances such as pavement wearing surfaces. All ten samples in this study have a flakiness index lower than $40 \%$.

\subsubsection{Strength and Toughness}

It is important that aggregate for making concrete be 'strong' in a general sense [30]. In most cases, inherent aggregate strength is dependent upon aggregate 'toughness', a property broadly analogous to 'impact strength'. In this study, ten percent fine values (TFV) and aggregate impact values (AIV) are used to determine the strength and toughness of the RA samples respectively.

The TFV measures aggregate resistance in crushing which is applicable to both weak and strong aggregate [31]; a higher value indicates that aggregate is more resistant in crushing [23]. The AIV measures aggregate resistance to sudden shock or impact [32]. A smaller AIV indicates that the aggregate is tougher or more impact resistant than aggregate with a higher AIV [23]. In the ten samples, Sample 6 has the highest value of TFV and the lowest 
value of AIV of about $155.53 \mathrm{kN}$ and $25 \%$ respectively; while Sample 2 has the lowest value of TFV and the highest value of AIV of about $61 \mathrm{kN}$ and $36 \%$ respectively as shown in Table 5. The obvious reason for this is that the cement paste attached to the RA directly affects the aggregate strength. The accuracy of more than $50 \%$ can be obtained based on the relation between TFV and AIV given by Equation 32:

$$
A I V_{r a}=-0.1317 T F V_{r a}+43.96 \quad\left(R^{2} \approx 0.5417\right) \quad \text { Equation } 32
$$

where $T F V$ is the ten percent fine value of aggregate (in $\mathrm{kN}$ ); and $A I V$ the aggregate impact value (in \%).

BS 882 [22] provides limits for the minimum TFV and maximum AIV of about $150 \mathrm{kN}$ and $45 \%$ respectively according to the concrete type in which the aggregate is used. According to British Standard requirements, Samples 6 can be used for structural elements, Samples 4 and 7 for pavement work and other samples confined to non-structural elements.

\subsubsection{Chloride and Sulphate Contents}

It is important to keep RA chloride and sulphate contents below a certain level. RA chloride contamination derived from marine structures or similarly exposed structural element is of concern which can lead to corrosion of steel reinforcement. However, for most RA samples (Samples 1 to 6 and 8 to 10), chloride ion contents are low and within the limit of standards of under $0.05 \%$. Nevertheless, Sample 7 falls beyond the limit with the chloride contents of about $0.10 \%$ and $0.09 \%$ for $10 \mathrm{~mm}$ and $20 \mathrm{~mm}$ aggregate respectively as shown in Table 5 . From further investigation of Sample 7, some shell (from fine marine aggregates) contents were found. One of the major reasons comes from the use of marine water or stream water 
in concrete mixing during the drought period in the 1960s, which was banned since 1970s. This could have increased the chloride content in the sample.

Occurrence of sulphate-based products such as gypsum as contaminants in DC is common. Consideration must be given to use sulphate resisting cement in situations where gypsum contamination is suspected [33]. In addition, gypsum plaster is seldom used in Hong Kong where lime plaster is more common. In fact, the highest sulphate content recorded is about $0.03 \%$ for Sample 1, which still falls within the standard of $1 \%$ as shown in Table 5. Therefore, sulphate content contamination is not a major problem for RA in Hong Kong.

Equation 33 shows a strong relationship between the chloride content for $10 \mathrm{~mm}$ and 20 $\mathrm{mm}$ aggregate with the correlation coefficient of about $99.5 \%$.

$$
C_{r a 20}=0.8691 C_{r a 10}+0.0001 \quad\left(R^{2} \approx 0.9949\right) \quad \text { Equation } 33
$$

where $C_{r a 10}$ is the chloride content for $10 \mathrm{~mm}$ aggregate; and $C_{r a 20}$ the chloride content for $20 \mathrm{~mm}$ aggregate.

Furthermore, Equation 17 to Equation 23 and Equation 25 to Equation 31 show strong correlation among the properties of the DC samples and their RA properties. It can be concluded that the lower the quality of DC samples, the lower the quality of their RA will be. Although most construction and demolition sites will not measure the quality of DC before crushing it to create RA, it may be important to measure the behaviour of DC to provide a pre-requisite consideration for their RA applications. This can save time and cost 
for the production of inferior quality RA and ensure that high quality RA is produced for higher-grade concrete applications.

\subsection{Recycled Aggregate Concrete}

To verify the above results, compressive strengths of $100 \mathrm{~mm}$ cubes made from the ten samples were measured according to BS 1881: Part 116 [34]. According to Buildings Department's requirements [6], mix proportions and design requirements for RAC are stated in Table 8. All the samples have achieved the required requirements. The average and the individual results of three cubes of each sample are tabulated in Table 6. Since limited samples are collected from the various demolition sites, samples verified by the concrete cubes are used as the base. The results show that the compressive strength of RAC made from Sample 6 has reached about $63 \mathrm{MPa}$. The lowest strength was recorded for Samples 7 and 8 with values of about $50 \mathrm{MPa}$.

$<$ Table 8>

From the correlation results showed in Table 7 , the compressive strength for the RAC samples show relationships with density, absorptivity, porosity, and carbonation depth of the DC samples as shown in Equation 34 to Equation 37.

$$
\begin{array}{lll}
D_{d c}=13.219 S_{r a c}+1637.4 & \left(R^{2} \approx 0.7942\right) & \text { Equation } 34 \\
A_{d c}=-0.4102 S_{r a c}+27.442 & \left(R^{2} \approx 0.7489\right) & \text { Equation } 35 \\
P_{d c}=-0.2935 S_{r a c}+32.085 & \left(R^{2} \approx 0.415\right) & \text { Equation } 36 \\
C D_{d c}=-0.1621 S_{r a c}+10.137 & \left(R^{2} \approx 0.5576\right) & \text { Equation } 37
\end{array}
$$

where $S_{r a c}$ is the compressive strength of RAC (in MPa). 
Equation 38 and Equation 41 show relationships between the strength of the RAC samples and the properties of their RA.

$$
\begin{array}{lll}
D_{\text {ra10 }}=0.009 S_{\text {rac }}+1.6891 & \left(R^{2} \approx 0.6191\right) & \text { Equation } 38 \\
D_{\text {ra20 }}=0.0091 S_{\text {rac }}+1.6924 & \left(R^{2} \approx 0.6187\right) & \text { Equation } 39 \\
W A_{\text {ra10 }}=-0.2088 S_{\text {rac }}+18.426 & \left(R^{2} \approx 0.6489\right) & \text { Equation 40 } \\
W A_{\text {ra20 }}=-0.1533 S_{\text {rac }}+15.154 & \left(R^{2} \approx 0.8305\right) & \text { Equation 41 }
\end{array}
$$

Equation 1 to Equation 41 highlight that there are correlations among properties of the DC samples, their RA properties, and the compressive strength of RAC. It is clear that the inferior quality of the DC can lower the quality of their RA and RAC. One of the major problems in lowering the quality of DC, RA and RAC is cement mortar attached on the samples. With large pores and voids commonly occur around aggregate for most samples (see Figure 4), this creates a weak link between aggregate and old cement mortar and limits their concrete applications [35].

\section{$<$ Figure 4>}

The existence of pores and voids near aggregate region of the samples can be explained by the following six major issues [36-41, 18, 42-55]:

(a) Inadequate concrete mixing time creating large pores;

(b) Coarse aggregate trapping some voids underneath as shown in Figure 5;

(c) Expansion and shrinkage of aggregate lying under the surface of concrete; 
(d) Inappropriate water to cement ratio, either too dry or too wet causing the formation of pores;

(e) Moisture content in the environment affecting the water content of aggregate and thus pore generation; and

(f) Alkali-aggregate reaction, such as alkali-silica reaction, alkali-silicate reaction and alkali-carbonate reaction, may lower concrete quality. As alkalis are derived from the cement itself, sodium or potassium can contribute to the reaction provided that the alkali can move into pore solution of concrete and creates the necessary hydroxyl ion.

$<$ Figure 5>

As buildings would have normally serviced for many years before demolition, the properties and behaviour of concrete would obviously be affected during the service life. However, one of the major factors for the inferior quality of concrete waste is resulted from the poor workmanship and lack of supervision during concreting activities (see Table 9). Therefore, the construction industry should provide measures; including training and onsite supervision to reduce these problems in the future and thus improving DC, RA and RAC quality for higher-grade applications.

<Table 9>

\section{Conclusion}

In this paper, ten demolished concrete (DC) samples have been collected to investigate the correlation among the characteristics of DC, properties of recycled aggregate (RA) and 
recycled aggregate concrete (RAC). Four properties of the DC samples: i) density; ii) absorptivity; iii) porosity; and iv) carbonation depth; six properties of their RA: i) particle size distribution; ii) particle density; iii) porosity and absorption; iv) particle shape; v) strength and toughness; and vi) chemical and sulphate contents; and compressive strength of RAC, are examined. From the results, it is clear that there are correlations among the characteristics of the DC samples, and their RA and RAC. It is shown that the inferior quality of DC can lower the quality of their RA and RAC. It is important to measure the characteristics of DC to provide a pre-requisite consideration for their RA and RAC applications. This can save time and cost for the production of inferior quality RA and ensure that high quality RA is produced for higher-grade concrete applications. RAC design requirements can also be developed at the initial concrete demolition stage. Recommendations are also given to improve the future concreting practice.

\section{Acknowledgments}

The work described in this paper was fully supported by a grant from the Housing Authority Research Fund of the Hong Kong Special Administrative Region, China (Project Ref. No. 9460004).

The author is also grateful to the anonymous reviewers for constructive comment which improved the paper.

\section{References}

[1] J. Ferguson, N. Kermode, C.L. Nash, W.A.J. Sketch, R.P. Huxford. Managing and minimizing construction waste: a practical guide, ed. Engineers, I.o.C. London1995. 
[2] B.J. Sealey, P.S. Phillips, G.J. Hill. Waste management issues for the UK ready-mixed concrete industry. Resources, Conservation and Recycling 32(2001) 321-331.

[3] E.J. Craven, H.M. Okraglik, I.M. Eilenberg. Construction waste and a new design methodology. Sustainable Construction: Proceedings. Of the 1st Conference of CIB TG 16, 1994. p. 89-98.

[4] B. McDonald. RECON waste minimisation and environmental program. Proceedings of CIB Commission Meetings and Presentations. Melbourne, Australia: RMIT, 1996. p. 14-16.

[5] M.J. Rogoff, J.F. Williams. Approaches to implementing solid waste recycling facilities: Noyes, Park Ridge, NJ, 1994.

[6] Buildings Department. Use of recycled aggregates in concrete: practice note for authorized persons and registered structural engineers: Buildings Department, Hong Kong Special Administrative Region, 2005.

[7] Construction Industry Research and Information Association. Environmental issues in construction: a review of issues and initiatives relevant to the building, construction and related industries. London: Construction Industry Research and Information Association, 1993.

[8] C.F. Hendriks, H.S. Pietersen. Sustainable raw materials: construction and demolition waste. Cachan Cedex, France: RILEM Publication, 2000.

[9] S. Mindess, F. Young, D. Darwin. Concrete: Upper Saddle River, NJ: Prentice Hall, 2003.

[10] A.M. Neville. Properties of concrete: Burnt Mill, Harlow, Essex; New York, Longman, 1995. 
[11] W.M. Cross, K.H. Sabnis, L. Kjerengtroen, J.J. Kellar. Microhardness testing of fiberreinforced cement paste. ACI Materials Journal 97(2000) 162-167.

[12] M.F. Doerner, W.D. Nix. A method for interpreting the data fro depth sensing indentation instruments. Journal of Material Research 1(1986) 601-609.

[13] S. Igarashi, A. Bentur, S. Mindess. Microhardness testing of cementitious materials. Advanced Cement Based Materials 4(1996) 48-57.

[14] W.C. Oliver, G.M. Pharr. An improved technique for determining hardness and elastic modulus using load and displacement sensing indentation experiments. Journal of Material Research 7(1992) 1564-1579.

[15] P. Trtik, J.M.P. Bartos. Micromechanical properties of cementitious composites. Materials and Structure 32(1999) 388-393.

[16] V.G.F. Vander, G.M. Lucas. Microindentation hardness testing. Advanced Materials and Processes. (1998) 21-25.

[17] W. Zhu, J.M.P. Bartos. Assessment of interfacial microstructure and bond properties in aged GRC using a novel mircoindentation method. Cement and Concrete Research 27(1997) 1701-1711.

[18] D.A. John, A.W. Poole, I. Sims. Concrete petrography: a handbook of investigative techniques, ed. Sons, L.A.N.Y.J.W.1998.

[19] W. Manns, K. Wesche. Variation in strength of mortars made of different cements due to carbonation. Proceedings of the 5th International Symposium on the Chemistry of Cements III. Tokyo: Cement Association of Japan, 1968. p. 385-393.

[20] A. Meyer. Investigations on the carbonation of concrete. Proceedings 5th International Symposium, Chemistry of Cement 3, 1968. p. 394-401. 
[21] J.H. Brown. The effect of exposure and concrete quality: field survey results from some 400 structures. Proceedings of the 5th International Conference on the Durability of Materials and Components. Bringhton, 1991. p. 249-259.

[22] BS 882. Specification for aggregates from natural sources for concrete: British Standards Institution, London, United Kingdom, 1992.

[23] P.C. Hewlett. Lea's chemistry of cement and concrete: London: Arnold 1998.

[24] BS 812: Part 2. Methods for determination of density: British Standards Institution, London, United Kingdom, 1995.

[25] T.C. Hansen, H. Narud. Strength of recycled concrete made from crushed concrete coarse aggregate. Concrete International: Design and Construction. 5(1983) 79-83.

[26] S. Kobayashi, H. Kawano, Properties and usage of recycled aggregate concrete. Demolition and reuse of concrete and masonry: reuse of demolition waste, London: Chapman and Hall, 547-556, (1988).

[27] J.F. Lamond, R.L. Campbell, J.A. Campbell, A. Giraldi, W. Halczak, H.C. Hale, N.J.T. Jenkins, R. Miller, P.T. Seabrook. Removal and reuse of hardened concrete: reported by ACI committee 555. ACI Materials Journal 99(2002) 300-325.

[28] BS 812: Part 105.1. Flakiness index: British Standards Institution, London, United Kingdom, 1989.

[29] BS 812: Part 105.2. Elongation index of coarse aggregate: British Standards Institution, London, United Kingdom, 1989.

[30] Oklahoma State University. Recycled Aggregate. From http://osu.okstate.edu/ 2006

[31] BS 812: Part 111. Methods for determination of ten per cent fines value (TFV): British Standards Institution, London, United Kingdom, 1990. 
[32] BS 812: Part 112. Methods for determination of aggregate impact value (AIV): British Standards Institution, London, United Kingdom, 1990.

[33] K.S. Crentsil, T. Brown. Guide for specification of recycled concrete aggregate (RCA) for concrete production: final report. From Victoria, http://www.ecorecycle.vic.gov.au/asset/1/upload/Guide_for_Specification_of_Recy cled_Concrete_Aggregates_(RCA).pdf 1998

[34] BS 1881: Part 116. Method for determination of compressive strength of concrete cubes: British Standards Institution, London, United Kingdom 1983.

[35] W.Y.V. Tam, C.M. Tam. Parameters for assessing recycled aggregate and their correlation. Waste Management and Research. (2007) In Press.

[36] M.G. Alexander. The effects of ageing on the interfacial zone in concrete. Interfacial transition zone in concrete: state-of-the-art report. (1996) 150-174.

[37] A. Bentur, M.D. Cohen. Effect of condensed silica fume on the microstructure of the interfacial zone in Portland cement mortars. Journal of American Ceramic Society 70(1987) 738-743.

[38] S. Diamond, J. Huang. The interfacial transition zone: reality or myth? RILEM Second International Conference on the Interfacial Transition Zone in Cementitious Composites. Haifa, Isarel, 1998. p. 3-39.

[39] A.M. Fadhala, C.K. Hover. Rapid evaporation from freshly cast concrete and the Gulf environment. Construction and Building Materials 25(2000) 1-7.

[40] E.J. Garboczi, D.P. Bentz. Analytical formulas for interfacial transition zone properties. Advanced Cement Based Materials 6(1997) 99-108. 
[41] C.F. Goble, M.D. Cohen. Influence of aggregate surface area on mechanical properties of mortar. ACI Materials Journal. (1999) 657-662.

[42] K.O. Kjellsen, O.H. Wallevik, L. Fjallberg. Microstructure and microchemistry of the paste-aggregate interfacial transition zone of high-performance concrete. Advances in Cement Research 10(1998) 33-40.

[43] J.A. Larbi, J.M. Bijen. Orientation of calcium hydroxide at the Portland cement pasteaggregate interface in mortars in the presence of silica fume. Cement and Concrete Research 20(1990) 461-470.

[44] Y.T. Lo. 2000. Microstructure study of the aggregate/cement paste interfacial zone of lightweight concrete, in Department of Building and Construction, City University of Hong Kong: Hong Kong, China.

[45] K. Mitsui, Z. Li, D.A. Lange, S.P. Shah. Relationship between microstructure and mechanical properties of the paste-aggregate interface. ACI Materials Journal 91(1994) 30-39.

[46] A.R. Mohamed, W. Hansen. Micromechanical modeling of crack-aggregate interaction in concrete materials. Cement and Concrete Composites 21(1999) 349-359.

[47] P.J.M. Monteiro. 1985. Microstructure of concrete and its influence on the mechanical properties, University of California Berkeley.

[48] P.J.M. Monteiro, Mechanical modeling of the transition zone. Interfacial transition zone in concrete: state-of-the-art report, 64-74, (1996).

[49] P.J.M. Monteiro, J.C. Maso, J.P. Ollivier. The aggregate-mortar interface. Cement and Concrete Research. 15(1985) 953-958. 
[50] D. Palmer. The diagnosis of alkali-silica reaction: report of a working party: British Cement Association, Wexham Springs, Slough, United Kingdom, 1992.

[51] K.L. Scrivener, A. Bentur, P.L. Pratt. Quantitative characterization of the transition zone in high-strength concretes. Advances in Cement Research 1(1988) 230-237.

[52] K.L. Scrivener, E.M. Gartner. Microstructural gradients in cement paste around aggregate particles. Materials Research Society Symposium Proceedings. 114(1988) $77-85$.

[53] O.H. Wallevik, K.O. Kjellsen. A microstructural and microanalytical study of highstrength concretes with porous aggregate. Proceedings of the 4th International Symposium on the utilization of high strength / high performance concrete Volume 2. Paris 1996. p. 471-478.

[54] C.Z. Yuan, I. Odler. The interfacial zone between marble and tricalcium silicate paste. Cement and Concrete Research 20(1987) 784-792.

[55] M.H. Zhang, O.E. Gjora. Backscattered electron imaging studies on the interfacial zone between high-strength light-weight aggregate and cement paste. Advances in Cement Research 2(1989) 141-146.

[56] Construction Materials Recycling Association. From http://www.cdrecycling.org/ 2005

[57] Environmental Protection Department. From http://www.info.gov.hk/epd 2005

[58] C.S. Poon. Management and Recycling of Demolition Waste in Hong Kong. Proceedings, 2nd International Conference on Solid Waste Management. Taipei, Taiwan, 2000. p. 433-442. 
[59] W. Li. Composition analysis of construction and demolition waste and enhancing waste reduction and recycling in construction industry in Hong Kong: Department of Building and Real Estate, The Hong Kong Polytechnic University, Hong Kong, China, 2002.

[60] BS 1881: Part 114. Methods for determination of density of hardened concrete. United Kingdom: British Standard Institution, 1983.

[61] BS 812: Part 117. Methods for determination of water-soluble chloride salts: British Standards Institution, London, United Kingdom 1988.

[62] C.S. Poon, T.W. Yu, L.H. Ng. A guide for managing and minimizing building and demolition waste: The Hong Kong Polytechnic University, 2001.

[63] C.S. Poon, T.W. Yu, L.H. Ng. On-site sorting of construction and demolition waste in Hong Kong. Resources, Conservation and Recycling 32(2001) 157-172. 
Table 1: Comparison of proportions of construction solid waste $[56,57,8,58]$

\begin{tabular}{|c|c|c|}
\hline Country & Proportion of construction waste to total waste (\%) & C\&D waste recycled (\%) \\
\hline Australia & 44 & 51 \\
\hline Brazil & 15 & 8 \\
\hline Denmark & $25-50$ & 80 \\
\hline Finland & 14 & 40 \\
\hline France & 25 & $20-30$ \\
\hline Germany & 19 & 40 to 60 \\
\hline Hong Kong & 38 & No information \\
\hline Japan & 36 & 65 \\
\hline Italy & 30 & 10 \\
\hline Netherlands & 26 & 75 \\
\hline Norway & 30 & 7 \\
\hline Spain & 70 & 17 \\
\hline United Kingdom & Over 50 & 40 \\
\hline United States of America & 29 & 25 \\
\hline
\end{tabular}


Table 2: Composition of construction waste collected in South East New Territories (SENT) landfill [59]

\begin{tabular}{|c|c|c|c|c|}
\hline \multirow{2}{*}{ Waste type } & \multicolumn{4}{|c|}{ Percentage } \\
\cline { 2 - 5 } & Construction site & Demolition site & General civil work & Renovation work \\
\hline Metal & $4 \%$ & $5 \%$ & $10 \%$ & $5 \%$ \\
\hline Wood & $5 \%$ & $7 \%$ & $0 \%$ & $5 \%$ \\
\hline Plastic & $2 \%$ & $3 \%$ & $0 \%$ & $5 \%$ \\
\hline Paper & $2 \%$ & $2 \%$ & $0 \%$ & $1 \%$ \\
\hline Concrete & $\mathbf{7 5 \%}$ & $\mathbf{7 0 \%}$ & $\mathbf{4 0 \%}$ & $\mathbf{7 0 \%}$ \\
\hline Rock / Rubble & $2 \%$ & $1 \%$ & $5 \%$ & $0 \%$ \\
\hline Sand / Soil & $5 \%$ & $0 \%$ & $40 \%$ & $0 \%$ \\
\hline Glass / Tile & $3 \%$ & $2 \%$ & $0 \%$ & $10 \%$ \\
\hline Others & $2 \%$ & $10 \%$ & $5 \%$ & $100 \%$ \\
\hline Total: & $100 \%$ & $100 \%$ & $100 \%$ & \\
\hline
\end{tabular}


Table 3: Standards used for experimental work

\begin{tabular}{|c|c|}
\hline Demolished concrete & Standard \\
\hline \multicolumn{2}{|l|}{ Density } \\
\hline Density & BS 1881: Part 114 [60] \\
\hline \multicolumn{2}{|l|}{ Absorptivity } \\
\hline Water absorption & BS 812: Part 2 [24] \\
\hline \multicolumn{2}{|l|}{ Porosity } \\
\hline Mercury intrusion porosimetry (MIP) & Manual of micromeritics poresizer 9320 \\
\hline \multicolumn{2}{|l|}{ Carbonation depth } \\
\hline Fourier transform of infrared spectroscopy (FT-IR) & $\begin{array}{l}\text { Manual of FT-IR spectrometer spectrum } \\
1000 \text { (Perkin Elmer) }\end{array}$ \\
\hline \multicolumn{2}{|l|}{ Recycled aggregate } \\
\hline \multicolumn{2}{|l|}{ Particle size distribution } \\
\hline Sieve analysis & BS 882 [22] \\
\hline \multicolumn{2}{|l|}{ Particle density } \\
\hline Particle density on oven-dried basis & BS 812: Part 2 [24] \\
\hline \multicolumn{2}{|l|}{ Porosity and absorption } \\
\hline Water absorption & BS 812: Part 2 [24] \\
\hline \multicolumn{2}{|l|}{ Particle shape } \\
\hline Flakiness index & BS 812: Part 105.1 [28] \\
\hline \multicolumn{2}{|l|}{ Strength and toughness } \\
\hline Ten percent fine value (TFV) & BS 812: Part 111 [31] \\
\hline Aggregate impact value (AIV) & BS 812: Part 112 [32] \\
\hline \multicolumn{2}{|l|}{ Chemical composition } \\
\hline Chloride content & BS 812: Part 117 [61] \\
\hline Sulphate content & Manual of ion chromatography \\
\hline \multicolumn{2}{|l|}{ Recycled aggregate concrete } \\
\hline Compressive strength & BS 1881: Part 116 [34] \\
\hline
\end{tabular}


Table 4: Summary of results on demolished concrete samples

\begin{tabular}{|c|c|c|c|c|c|c|}
\hline \multirow{2}{*}{ Sample } & \multirow{2}{*}{$\begin{array}{c}\text { Density } \\
\left(\text { in } \mathrm{Mg} / \mathrm{m}^{3}\right)\end{array}$} & \multirow{2}{*}{$\begin{array}{c}\text { Absorptivity } \\
\text { (in } \%)\end{array}$} & \multirow{2}{*}{$\begin{array}{l}\text { Porosity } \\
\text { (in } \% \text { ) }\end{array}$} & \multicolumn{3}{|c|}{ Carbonation depth } \\
\hline & & & & $\mathrm{CDI}$ of $\mathrm{CO}_{2}$ & $\mathrm{CDI}$ of $\mathrm{CO}$ & $\mathrm{CDI}^{*}$ \\
\hline 1 & 2.341 & 3.87 & 14.40 & 0.73 & 0.51 & 0.62 \\
\hline 2 & 2.425 & 4.41 & 13.94 & 0.86 & 1.20 & 1.03 \\
\hline 3 & 2.362 & 4.14 & 15.54 & 1.54 & 1.50 & 1.52 \\
\hline 4 & 2.331 & 6.64 & 16.00 & 1.14 & 1.70 & 1.42 \\
\hline 5 & 2.321 & 5.23 & 16.37 & 0.86 & 1.16 & 1.01 \\
\hline 6 & 2.432 & 1.98 & 14.30 & 0.29 & 0.53 & 0.41 \\
\hline 7 & 2.271 & 8.93 & 20.41 & 3.22 & 3.54 & 3.38 \\
\hline 8 & 2.269 & 7.01 & 17.96 & 1.86 & 2.60 & 2.23 \\
\hline 9 & 2.410 & 4.93 & 15.40 & 0.54 & 0.36 & 0.45 \\
\hline 10 & 2.430 & 3.33 & 16.25 & 0.62 & 0.94 & 0.78 \\
\hline \multicolumn{7}{|c|}{$\begin{array}{l}\text { Note: } \\
\text { * Carbonation Depth Index }(C D I)=\frac{\sum_{n=1}^{4} Q_{C n}-Q_{C 5}}{Q_{C 5}} \text {, where } Q_{C n} \text { is the quantity of } \mathrm{CO} \text { or } \mathrm{CO}_{2} \text { of } \\
\text { the n-layer of cement paste, } Q_{C 5} \text { is the quantity of } \mathrm{CO} \text { or } \mathrm{CO}_{2} \text { of the fifth layer of cement } \\
\text { paste and } Q_{C n} \text { should be larger than } Q_{C 5} \text {. }\end{array}$} \\
\hline
\end{tabular}


Table 5: Summary of results on recycled aggregate

\begin{tabular}{|c|c|c|c|c|c|c|c|c|c|c|c|c|c|}
\hline \multirow{3}{*}{ Sample } & \multirow{2}{*}{\multicolumn{2}{|c|}{$\begin{array}{c}\begin{array}{c}\text { Particle size } \\
\text { distribution }\end{array} \\
\text { Sieve analysis }\end{array}$}} & \multirow{2}{*}{\multicolumn{2}{|c|}{$\begin{array}{c}\text { Density } \\
\text { Particle density } \\
(\mathrm{Mg} / \mathrm{m} 3) \\
\end{array}$}} & \multirow{2}{*}{\multicolumn{2}{|c|}{$\begin{array}{c}\begin{array}{c}\text { Porosity and } \\
\text { absorption }\end{array} \\
\text { Water absorption }(\%)\end{array}$}} & \multirow{2}{*}{\multicolumn{2}{|c|}{$\begin{array}{c}\text { Particle shape } \\
\text { Flakiness index }(\%)\end{array}$}} & \multicolumn{2}{|c|}{$\begin{array}{c}\text { Strength and } \\
\text { toughness }\end{array}$} & \multicolumn{3}{|c|}{ Chloride and sulphate contents } \\
\hline & & & & & & & & & \multirow{2}{*}{$\begin{array}{l}\mathrm{TFV} \\
(\mathrm{kN})\end{array}$} & \multirow{2}{*}{$\begin{array}{l}\text { AIV } \\
(\%)\end{array}$} & \multicolumn{2}{|c|}{$\begin{array}{l}\text { Chloride content } \\
(\%)\end{array}$} & \multirow{2}{*}{$\begin{array}{l}\text { Sulphate } \\
\text { content } \\
(\%)\end{array}$} \\
\hline & $10 \mathrm{~mm}$ & $20 \mathrm{~mm}$ & $10 \mathrm{~mm}$ & $20 \mathrm{~mm}$ & $10 \mathrm{~mm}$ & $20 \mathrm{~mm}$ & $10 \mathrm{~mm}$ & $20 \mathrm{~mm}$ & & & $10 \mathrm{~mm}$ & $20 \mathrm{~mm}$ & \\
\hline 1 & Pass & Pass & 2.16 & 2.20 & 5.83 & 6.89 & 11.13 & 9.68 & 93.89 & 33 & 0.0078 & 0.0089 & 0.031 \\
\hline 2 & Pass & Pass & 2.22 & 2.14 & 6.36 & 6.40 & 10.44 & 10.08 & 61.36 & 36 & 0.0108 & 0.0091 & 0.017 \\
\hline 3 & Pass & Pass & 2.20 & 2.18 & 7.50 & 7.35 & 15.17 & 8.61 & 107.42 & 31 & 0.0013 & 0.0019 & 0.005 \\
\hline 4 & Pass & Pass & 2.20 & 2.20 & 6.93 & 7.25 & 15.42 & 7.91 & 112.82 & 23 & 0.0019 & 0.0019 & 0.005 \\
\hline 5 & Pass & Pass & 2.15 & 2.19 & 7.31 & 6.82 & 17.82 & 12.96 & 92.09 & 32 & 0.0054 & 0.0061 & 0.006 \\
\hline 6 & Pass & Pass & 2.25 & 2.27 & 5.20 & 5.77 & 11.96 & 9.93 & 155.53 & 25 & 0.0008 & 0.0025 & 0.006 \\
\hline 7 & Pass & Pass & 2.11 & 2.13 & 8.74 & 7.30 & 12.86 & 5.70 & 110.18 & 30 & 0.0976 & 0.0902 & 0.013 \\
\hline 8 & Pass & Pass & 2.10 & 2.12 & 8.58 & 7.99 & 15.12 & 9.78 & 83.48 & 34 & 0.0013 & 0.0014 & 0.005 \\
\hline 9 & Pass & Pass & 2.21 & 2.24 & 6.94 & 6.11 & 13.78 & 12.17 & 92.87 & 36 & 0.0459 & 0.0352 & 0.024 \\
\hline 10 & Pass & Pass & 2.20 & 2.23 & 6.85 & 5.95 & 16.47 & 9.92 & 89.91 & 28 & 0.0494 & 0.0430 & 0.018 \\
\hline
\end{tabular}


Table 6: Summary of results on recycled aggregate concrete

\begin{tabular}{|c|c|c|}
\hline Sample & Test & Compressive strength (in $\mathrm{MPa}$ ) \\
\hline \multirow{4}{*}{1} & 1 & 56 \\
\hline & 2 & 54 \\
\hline & 3 & 55 \\
\hline & Average & 55 \\
\hline \multirow{4}{*}{2} & 1 & 56 \\
\hline & 2 & 57 \\
\hline & 3 & 56 \\
\hline & Average & 56 \\
\hline \multirow{4}{*}{3} & 1 & 53 \\
\hline & 2 & 53 \\
\hline & 3 & 52 \\
\hline & Average & 53 \\
\hline \multirow{4}{*}{4} & 1 & 50 \\
\hline & 2 & 51 \\
\hline & 3 & 51 \\
\hline & Average & 51 \\
\hline \multirow{4}{*}{5} & 1 & 52 \\
\hline & 2 & 51 \\
\hline & 3 & 51 \\
\hline & Average & 52 \\
\hline \multirow{4}{*}{6} & 1 & 65 \\
\hline & 2 & 62 \\
\hline & 3 & 62 \\
\hline & Average & 63 \\
\hline \multirow{4}{*}{7} & 1 & 51 \\
\hline & 2 & 50 \\
\hline & 3 & 48 \\
\hline & Average & 50 \\
\hline \multirow{4}{*}{8} & 1 & 49 \\
\hline & 2 & 52 \\
\hline & 3 & 50 \\
\hline & Average & 50 \\
\hline \multirow{4}{*}{9} & 1 & 58 \\
\hline & 2 & 58 \\
\hline & 3 & 55 \\
\hline & Average & 57 \\
\hline \multirow{4}{*}{10} & 1 & 60 \\
\hline & 2 & 57 \\
\hline & 3 & 59 \\
\hline & era & 59 \\
\hline
\end{tabular}


Table 7: Correlation coefficients on demolished concrete, recycled aggregate and recycled aggregate concrete

\begin{tabular}{|c|c|c|c|c|c|c|c|c|c|c|c|}
\hline & \multirow{3}{*}{\multicolumn{2}{|c|}{ Correlation }} & \multicolumn{4}{|c|}{ Demolished concrete } & \multicolumn{4}{|c|}{ Recycled aggregate } & $\begin{array}{l}\text { Recycled aggregate } \\
\text { concrete }\end{array}$ \\
\hline & & & \multirow{2}{*}{ Density } & \multirow{2}{*}{ Absorptivity } & \multirow{2}{*}{ Porosity } & \multirow{2}{*}{$\begin{array}{c}\text { Carbonation } \\
\text { depth }\end{array}$} & \multicolumn{2}{|c|}{ Density } & \multicolumn{2}{|c|}{ Water absorption } & \multirow{2}{*}{ Strength } \\
\hline & & & & & & & $10 \mathrm{~mm}$ & $20 \mathrm{~mm}$ & $10 \mathrm{~mm}$ & $20 \mathrm{~mm}$ & \\
\hline \multirow{4}{*}{  } & \multicolumn{2}{|c|}{ Density } & 1.000 & 0.828 & 0.751 & 0.782 & 0.911 & 0.681 & 0.753 & 0.892 & 0.891 \\
\hline & \multicolumn{2}{|c|}{ Absorptivity } & 0.828 & 1.000 & 0.841 & 0.870 & 0.768 & 0.723 & 0.848 & 0.722 & 0.865 \\
\hline & \multicolumn{2}{|c|}{ Porosity } & 0.751 & 0.841 & 1.000 & 0.892 & 0.790 & 0.544 & 0.880 & 0.557 & 0.644 \\
\hline & \multicolumn{2}{|c|}{ Carbonation depth } & 0.782 & 0.870 & 0.892 & 1.000 & 0.744 & 0.780 & 0.854 & 0.726 & 0.747 \\
\hline \multirow{4}{*}{ 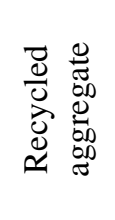 } & \multirow{2}{*}{ Density } & $10 \mathrm{~mm}$ & 0.911 & 0.768 & 0.790 & 0.744 & 1.000 & 0.721 & 0.794 & 0.764 & 0.787 \\
\hline & & $20 \mathrm{~mm}$ & 0.681 & 0.723 & 0.544 & 0.780 & 0.721 & 1.000 & 0.725 & 0.772 & 0.787 \\
\hline & \multirow{2}{*}{$\begin{array}{c}\text { Water } \\
\text { absorption }\end{array}$} & $10 \mathrm{~mm}$ & 0.753 & 0.848 & 0.880 & 0.854 & 0.794 & 0.725 & 1.000 & 0.731 & 0.806 \\
\hline & & $20 \mathrm{~mm}$ & 0.892 & 0.722 & 0.557 & 0.726 & 0.764 & 0.772 & 0.731 & 1.000 & 0.911 \\
\hline 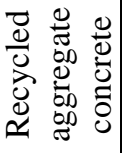 & \multicolumn{2}{|c|}{ Strength } & 0.891 & 0.865 & 0.644 & 0.747 & 0.787 & 0.787 & 0.806 & 0.911 & 1.000 \\
\hline
\end{tabular}


Table 8: Mix proportions and design requirements for RAC

\begin{tabular}{|c|c|}
\hline Mix proportions \\
\hline Ordinary Portland cement & \multicolumn{1}{|l|}{$100 \mathrm{~kg}$} \\
\hline Fine aggregate & $180 \mathrm{~kg}$ \\
\hline 20mm coarse aggregate & $180 \mathrm{~kg}$ \\
\hline Water & $90 \mathrm{~kg}$ \\
\hline Wesign requirements & \multicolumn{1}{|c|}{$45 \mathrm{~kg}$} \\
\hline \multicolumn{2}{|c|}{$\begin{array}{l}\text { Rorkability } \\
\text { thoroughly wetted before being used. } \\
\text { The concrete shall have a slump of 75mm } \\
\text { when it is ready to be compacted to its final } \\
\text { position. } \\
\text { All mixes are within 65mm to 85mm slump. }\end{array}$} \\
\hline $\begin{array}{l}\text { The minimum concrete } \\
\text { cube strength at 7 days }\end{array}$ & $14 \mathrm{MPa}$ \\
\hline $\begin{array}{l}\text { The minimum concrete } \\
\text { cube strength at 28 days }\end{array}$ & $20 \mathrm{MPa}$ \\
\hline
\end{tabular}


Table 9: Causes and examples of building waste on site [62, 63]

\begin{tabular}{|c|c|c|}
\hline Building waste & Causes of building waste on site & Examples \\
\hline \multirow{9}{*}{$\begin{array}{l}\text { Site } \\
\text { management } \\
\text { and practice }\end{array}$} & $\begin{array}{l}\text { Lack of a quality management system } \\
\text { aimed at waste minimization }\end{array}$ & Lack of waste management plan \\
\hline & Untidy construction sites & $\begin{array}{l}\text { Waste materials are not segregated from useful } \\
\text { materials }\end{array}$ \\
\hline & Poor handling & Breakage, damage, losses \\
\hline & $\begin{array}{l}\text { Over-sized foundations and other } \\
\text { elements }\end{array}$ & $\begin{array}{l}\text { Over design leads to excess excavation and cut- } \\
\text { offs }\end{array}$ \\
\hline & Inadequate protection to finished work & $\begin{array}{l}\text { Finished concrete staircases are not protected by } \\
\text { boarding }\end{array}$ \\
\hline & $\begin{array}{l}\text { Limited visibility on site resulting in } \\
\text { damage }\end{array}$ & Inadequate lighting in covered storage area \\
\hline & Poor storage & $\begin{array}{l}\text { Pallet is not used to protect cement bags from } \\
\text { contamination by ground water }\end{array}$ \\
\hline & Poor workmanship & Poor workmanship of formwork \\
\hline & $\begin{array}{l}\text { Waste generation inherited with } \\
\text { traditional construction method }\end{array}$ & Timber formwork, wet trade \\
\hline \multirow{4}{*}{$\begin{array}{l}\text { Delivery of } \\
\text { products }\end{array}$} & Over-ordering & Over ordering of concrete becomes waste \\
\hline & Method of packaging & Inadequate protection to the materials \\
\hline & Method of transport & Materials drop from forklift \\
\hline & $\begin{array}{l}\text { Inadequate data regarding time and } \\
\text { method of delivery }\end{array}$ & Lack of records concerning materials delivery \\
\hline
\end{tabular}






(a) Sample 1

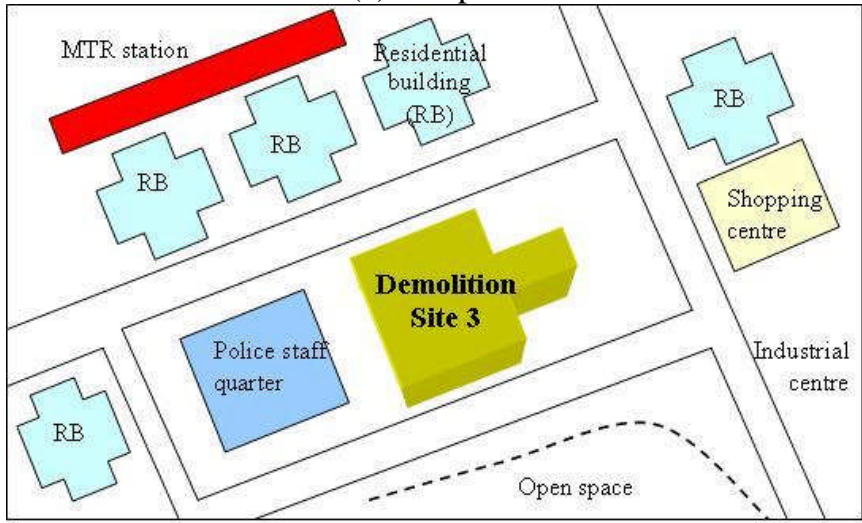

(c) Sample 3

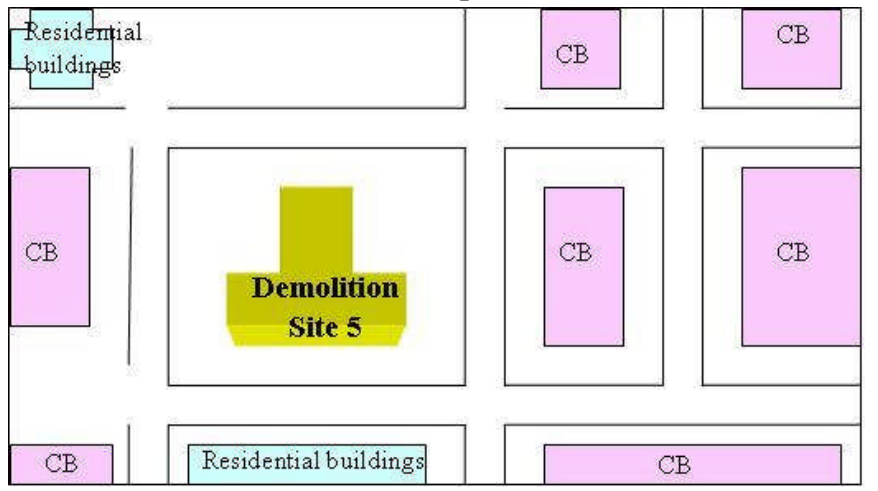

(e) Sample 5

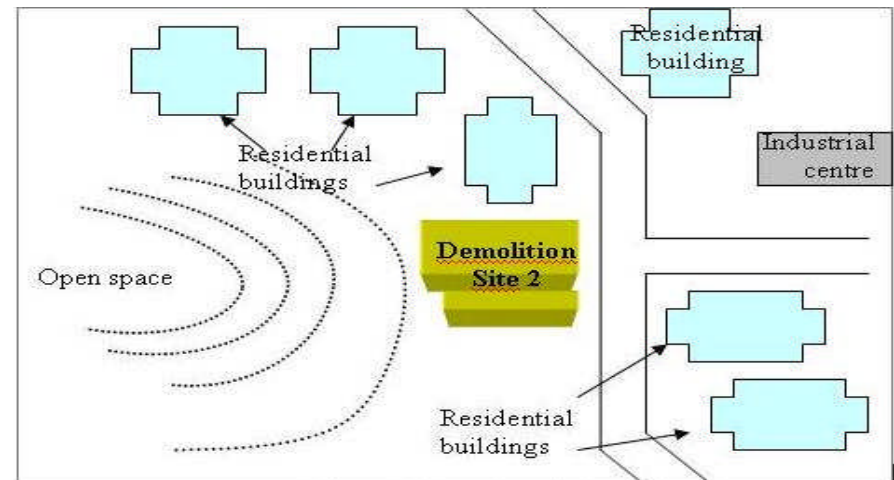

(b) Sample 2

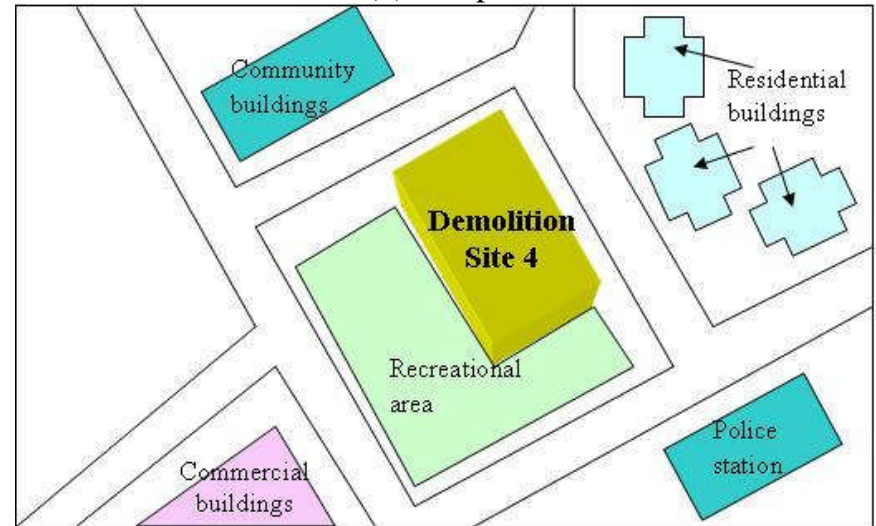

(d) Sample 4

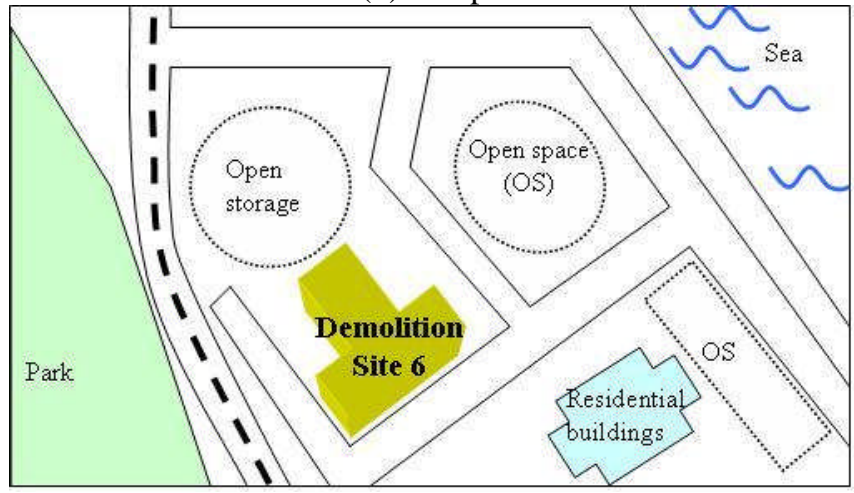

(f) Sample 6

Figure 1a: Locations for Samples 1 to 10 




(g) Sample 7

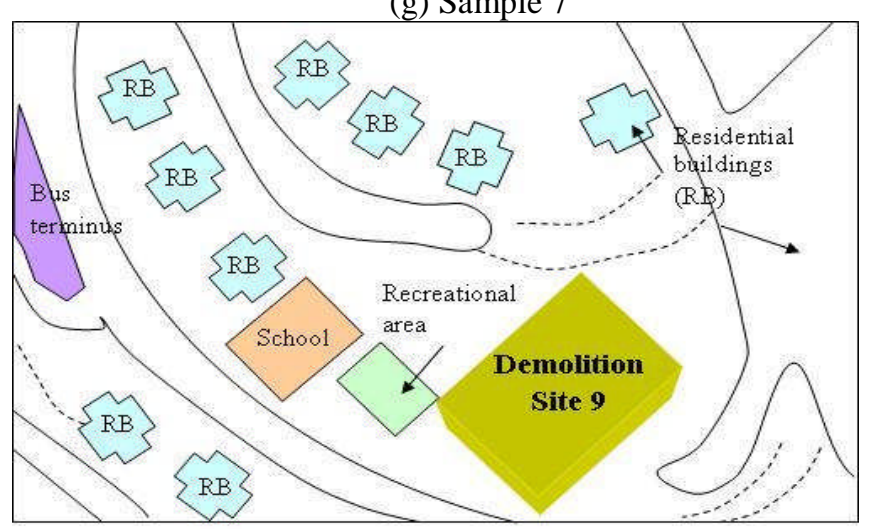

(i) Sample 9

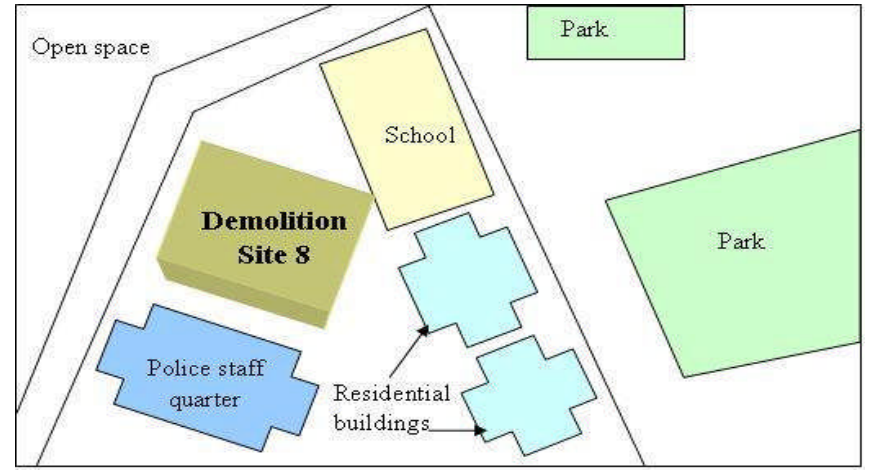

(h) Sample 8

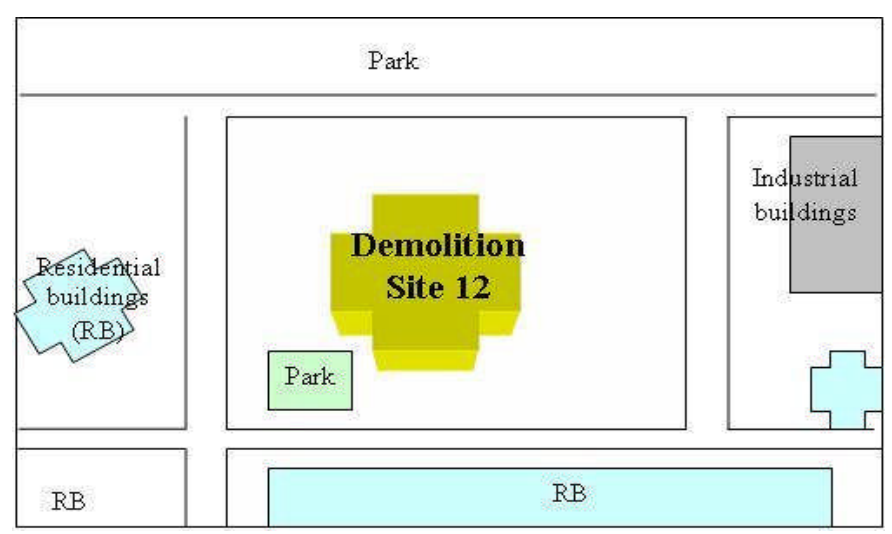

(j) Sample 10

Figure 1b: Locations for Samples 1 to 10 


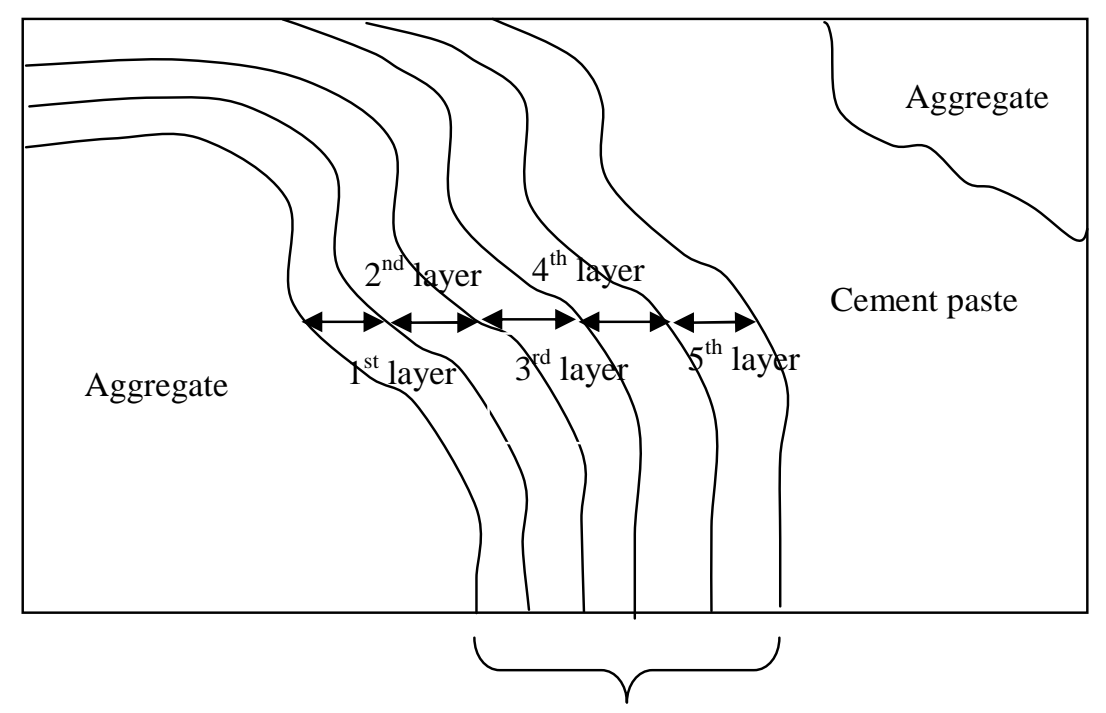

Near Aggregate Region

Figure 2: Five layers of cement sample near aggregate region for Fourier transform infrared spectroscopy examination 




Figure 3: Comparison of Fourier transform infrared spectroscopy absorbance spectra for Sample 3 (a) $1^{\text {st }}$ layer of cement paste; (b) $2^{\text {nd }}$ layer of cement paste; (c) $3^{\text {rd }}$ layer of cement paste; (d) $4^{\text {th }}$ layer of cement paste; and (e) $5^{\text {th }}$ layer of cement paste. 


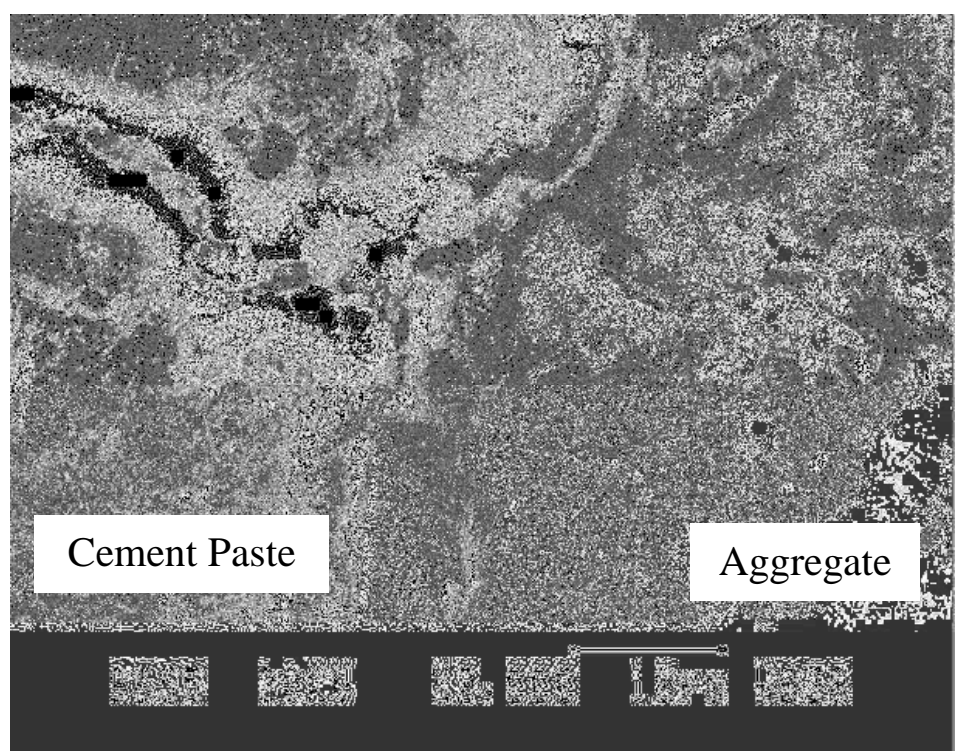

Figure 4: Scanning electron microcopy image on the interfacial transition zone 


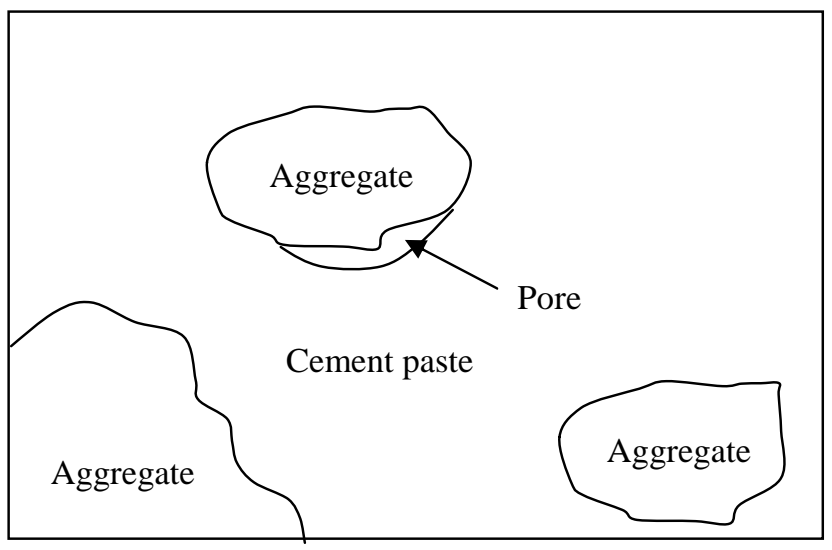

Figure 5: Schematic diagram showing formation of pores under aggregate during concreting 